\title{
Psychoeducational Interventions on Conflict Resolution Styles among Individuals Involved in Commuter Marriages
}

\author{
Qurrata A'yun ${ }^{1}$ \\ ${ }^{1}$ Master of Professional Psychology Program, Faculty of Psychology, Atma Jaya Catholic University \\ of Indonesia, Jakarta, Indonesia \\ qurrataayun@gmail.com, qurrataayun.201700040007@studentatmajaya.ac.id \\ Theresia Indira Shanti ${ }^{2}$ \\ ${ }^{2}$ Department of Psychology, Atma Jaya Catholic University of Indonesia, Jakarta, Indonesia \\ indira.shanti@atmajaya.ac.id
}

(Received July 01, 2021, accepted November 02, 2021)

\begin{abstract}
Couples in commuter marriages who live apart face many challenges, such as having ineffective communications which lead to conflict. Couples who use a positive and constructive conflict resolution style, have a better chance of getting a better quality of marital life. This intervention aims to provide psychoeducation to participants in order to understand conflict resolution styles that can be applied when dealing with and resolving conflicts in commuter marriages. The evaluation of the intervention effect was carried out by comparing the knowledge and skill to the application of conflict resolution styles, before and after the intervention. After being given psychoeducation, it was found that 25 participants changed the resolution style they would use when experiencing conflict with their partner. While the other 5 participants still chose the same resolution style. In conclusion, through this psychoeducation, participants have new knowledge about various resolution styles that can be used, and according to the conflict conditions experienced by each partner.
\end{abstract}

Keywords: conflict resolution; commuter marriage 


\section{Introduction}

Many married couples may live apart from each other due to factors related to work or pursuing education and each partner would have to mutually agree on a certain time to see each other (Beck, 2013; Dewi, 2013, in Nastiti \& Wismanto, 2017). Gross and Gerstel (1982) describes this condition as commuter marriage. Commuter marriages are not always easy for all couples. Compared to couples who live together, the main challenge is having to face the limitations in the intensity of direct interaction (Handayani, 2016; Maharani \& Kinanthi, 2018).

Handayani (2016) mentions that in couples in general commuter marriages would face challenges that lead to certain conflicts because they cannot fulfill their mutual needs. A'yun (2020) conducted a literature review and found that couples in commuter marriages are vulnerable and mostly face conflicts related to communication problems. Unresolved conflicts will contribute negatively to individuals' evaluation of the quality of their married life (A'yun, 2021). In addition to that, this condition can also negatively affect the couples' psychological condition. Gross (in Marriage and Family Encyclopedia, 2009) described the experiences shared by couples in commuter marriages which include emotional conditions for having to live apart from their partners, such as feelings of loneliness, stress, frustration and depression. Sandow (in Muliadi, 2017) found that among couples in commuter marriages that are not able to adjust themselves to adequately resolve their conflicts, $40 \%$ are more likely experience risk of divorce compared to couples living together and those who are able to resolve their conflicts effectively.

Although many negative impacts of unresolved conflicts were found, on the contrary some studies show that couples are able to develop or improve the quality of their marital relationships, when conflicts are resolved. Couples are able to experience this condition if they are able to understand and learn how to negotiate effectively and manage their own feelings (Mackey, Diemer, \& O’Brien, in Rosalia \& Priadi, 2018). Thus couples that are able to apply good conflict management strategies are able to maintain good and healthy marital relationships. Sadarjoen (2005) explained that marital conflicts occur because of difference of perceptions and expectations of each partner in facing marital problems, among others, differences in each partner's background and experiences and values they had prior to marital life. Based on these findings, couples are expected to be able to apply conflict resolution strategies as their main effort to resolve conflict. 
Nadia, Jannah and Bustaman (2017) found that using effective conflict resolution style will affect the couple's ability in problem solving, communications skills, quantity of understanding and about each other's character, and marital satisfaction and happiness. However, if couples apply ineffective conflict resolution styles, they will experience distress, face new problems, and may decide to end their relationship (Killis, in Nadia, Jannah \& Bustaman (2017). Thomas and Kilmann (1974) suggests that there are five types or styles of conflict resolutions, namely accommodative, compromising, collaborative, avoidance, and competitive styles.

Based on this literature review and finding on couples' conflicts and the negative and positive impact of conflict resolution among couples in commuter marriages, the researcher is interested in providing a psychosocial intervention on conflict resolution styles for individual who are in commuter marriages. Through this psychosocial intervention, the researcher hopes to contribute in educating participants about various conflict resolution styles that can be used and in accordance with the problem conditions when they undergo commuter marriages.

Griffiths (2006) stated that psychoeducation is a type of intervention given to an individual, family, or group which focuses on providing information and knowledge to participants so they may gain skills and capacity to face life challenges. Psychoeducation is also based on participants' strengths and is more focused on the present and future based on their past experience (Rahma \& Anwar, 2015). This intervention with the aim of providing psychoeducation to participants in order to be able to understand conflict resolution styles that can be applied when dealing with conflicts in commuter marriages. This psychoeducation also aims to determine the participants' understanding in choosing an effective conflict resolution style used before being given psychoeducation, and whether there are changes after being given psychoeducation.

\section{Method}

The method used in this intervention is in the form of psychoeducation, with modules that are based on theories about conflict resolution styles and qualitative data obtained from interviews with couples who are in communter marriages. This intervention was carried out in 3 sessions. In session 1, participants were given material about the conflict picture that is commonly experienced by commuter marriage couples. Session 2 participants were given psychoeducation about how couples deal with conflict and participants discussed their 
respective experiences. Then, in session 3 participants were given psychoeducation on various conflict resolution styles. Then, follow up to find out participants' knowledge about conflict resolution styles and the selection of styles that might be used when experiencing conflict.

To determine the effect of psychoeducation, participants will fill out pre and post instruments, with questions about the meaning of conflict resolution and various styles of conflict resolution. Questions given in the pre and post test (actual questions were given in Indonesian Language):

1. What do you know about conflict resolution?

2. Name and explain the types of conflict resolution styles?

3. What do you know about competitive, collaborative, compromise, avoidance, and accommodating styles?

4. Which of the following is an example of a competitive style?

5. Which of the following is an example of a collaborative style?

6. Which of the following is an example of a compromise style?

7. Which of the following is an example of an avoidance style?

8. Which of the following is an example of an accommodating style?

Participants also filled out statements about individual attitudes in resolving conflicts based on five types of conflict resolution (competitive, compromise, accommodative, elaborative and avoidance). The same instrument was given to the participants after the psychoeducational treatment (post-test). Several statements were given regarding the participants' attitudes when facing conflict, as follows (actual statements were given in Indonesian Language):

Table 1. Pretest and post questionnaire

\begin{tabular}{cl}
\hline No. & Statement \\
\hline 1. & At present time, it is easy for me to express anger, by saying harshly to my partner and \\
blaming him/her for the problems that are going on. \\
5. At present time, i don't want to interact with my partner to avoid trouble. \\
9 At present time, i easily take decisions or actions so that my problems and my partner's are \\
resolved, without thinking about the impact on our relationship.
\end{tabular}

The data analysis technique used in this activity is to use Paired Sample T test to compare mean knowledge before and after psieducation. And using a one group pretest posttest design approach to find out if there is a change in the chosen style to resolve conflicts in the future. The design is as follows 
Table 2. Research design

\begin{tabular}{lll}
\hline $\mathrm{O}_{1}$ & $\mathrm{X}$ & $\mathrm{O}_{2}$ \\
\hline
\end{tabular}

$\mathrm{O}_{1}$ is the result of the pretest before treatment. $\mathrm{O}_{2}$ is the posttest result after treatment, while $\mathrm{X}$ is psychoeducation about conflict resolution style as treatment. Pre and post test were given to find out whether participants continued to use the same style after being given psychoeducation, or changed the style to a more appropriate and effective style to use.

\section{Results and Discussions}

\section{Result}

Based on the statistical analysis of the Paired Sample T-test, it is known that there is a significant difference in knowledge about conflict resolution styles (Sig. 2 tailed $0.001<0.05$ ) before and after being given treatment (psychoeducation). This shows that participants' knowledge after psychoeducation activities was significantly higher than before psychoeducation. This indicates that this activity significantly increases the knowledge of the participant regarding conflict resolution styles.

Then, the evaluation results in Table 3 show the results of psychoeducation, table 3 shows the results of the intervention, 25 of 30 participants experienced a change in conflict resolution style after psychoeducation treatment. Among these 25 participants, the resolution style was accommodative, competitive, avoidance, compromising, changing to choose a collaborative style to use when later facing problems. Meanwhile, the other 5 participants showed no change in deciding the same conflict resolution style they used before, namely by using the collaborative, comprising and avoidance styles. This shows that 5 participants considered their resolution style they have used is appropriate and effective in solving problems in a relationship. 
Table 3. Pretest and posttest results

\begin{tabular}{|c|c|c|c|}
\hline Participant & $\begin{array}{c}\mathrm{O}_{1} \\
\text { (conflict resolution style } \\
\text { before psychoeducational } \\
\text { intervention) }\end{array}$ & $\begin{array}{c}\mathrm{O}_{2} \\
\text { (conflict resolution style after } \\
\text { psychoeducational } \\
\text { intervention) }\end{array}$ & Results \\
\hline 1 & Accommodative & Collaborative & $\begin{array}{l}\text { Changes in resolutions style found after } \\
\text { psychoeducational intervention. }\end{array}$ \\
\hline 2 & Competitive & Collaborative & $\begin{array}{l}\text { Changes in resolutions style found after } \\
\text { psychoeducational intervention }\end{array}$ \\
\hline 3 & Avoidance & Collaborative & $\begin{array}{l}\text { Changes in resolutions style found after } \\
\text { psychoeducational intervention }\end{array}$ \\
\hline 4 & Avoidance & Collaborative & $\begin{array}{l}\text { Changes in resolutions style found after } \\
\text { psychoeducational intervention }\end{array}$ \\
\hline 5 & Competitive & Collaborative & $\begin{array}{l}\text { Changes in resolutions style found after } \\
\text { psychoeducational intervention }\end{array}$ \\
\hline 6 & Compromising & Collaborative & $\begin{array}{l}\text { Changes in resolutions style found after } \\
\text { psychoeducational intervention. }\end{array}$ \\
\hline 7 & Avoidance & Collaborative & $\begin{array}{l}\text { Changes in resolutions style found after } \\
\text { psychoeducational intervention. }\end{array}$ \\
\hline 8 & Avoidance & Avoidance & $\begin{array}{l}\text { Changes in resolutions style not found after } \\
\text { psychoeducational intervention }\end{array}$ \\
\hline 9 & Accommodative & Collaborative & $\begin{array}{l}\text { Changes in resolutions style found after } \\
\text { psychoeducational intervention }\end{array}$ \\
\hline 10 & Avoidance & Collaborative & $\begin{array}{l}\text { Changes in resolutions style found after } \\
\text { psychoeducational intervention }\end{array}$ \\
\hline 11 & Avoidance & Collaborative & $\begin{array}{l}\text { Changes in resolutions style found after } \\
\text { psychoeducational intervention }\end{array}$ \\
\hline 12 & Competitive & Collaborative & $\begin{array}{l}\text { Changes in resolutions style found after } \\
\text { psychoeducational intervention }\end{array}$ \\
\hline 13 & Competitive & Collaborative & $\begin{array}{l}\text { Changes in resolutions style found after } \\
\text { psychoeducational intervention }\end{array}$ \\
\hline 14 & Compromising & Compromising & $\begin{array}{l}\text { Changes in resolutions style not found after } \\
\text { psychoeducational intervention. }\end{array}$ \\
\hline 15 & avoidance & Collaborative & $\begin{array}{l}\text { Changes in resolutions style found after } \\
\text { psychoeducational intervention }\end{array}$ \\
\hline 16 & Avoidance & Collaborative & $\begin{array}{l}\text { Changes in resolutions style found after } \\
\text { psychoeducational intervention }\end{array}$ \\
\hline 17 & Avoidance & Collaborative & $\begin{array}{l}\text { Changes in resolutions style found after } \\
\text { psychoeducational intervention }\end{array}$ \\
\hline 18 & Compromising & Collaborative & $\begin{array}{l}\text { Changes in resolutions style found after } \\
\text { psychoeducational intervention }\end{array}$ \\
\hline 19 & Avoidance & Collaborative & $\begin{array}{l}\text { Changes in resolutions style found after } \\
\text { psychoeducational intervention }\end{array}$ \\
\hline 20 & Compromising & Compromising & $\begin{array}{l}\text { Changes in resolutions style not found after } \\
\text { psychoeducational intervention. }\end{array}$ \\
\hline 21 & Accommodative & Collaborative & $\begin{array}{l}\text { Changes in resolutions style found after } \\
\text { psychoeducational intervention }\end{array}$ \\
\hline 22 & Avoidance & Collaborative & $\begin{array}{l}\text { Changes in resolutions style found after } \\
\text { psychoeducational intervention }\end{array}$ \\
\hline 23 & Collaborative & Collaborative & $\begin{array}{l}\text { Changes in resolutions style not found after } \\
\text { psychoeducational intervention. }\end{array}$ \\
\hline 24 & Compromising & Collaborative & $\begin{array}{l}\text { Changes in resolutions style found after } \\
\text { psychoeducational intervention }\end{array}$ \\
\hline 25 & Compromising & Collaborative & $\begin{array}{l}\text { Changes in resolutions style found after } \\
\text { psychoeducational intervention }\end{array}$ \\
\hline 26 & Collaborative & Collaborative & $\begin{array}{l}\text { Changes in resolutions style not found after } \\
\text { psychoeducational intervention. }\end{array}$ \\
\hline 27 & Competitive & Collaborative & $\begin{array}{l}\text { Changes in resolutions style found after } \\
\text { psychoeducational intervention }\end{array}$ \\
\hline 28 & Competitive & Collaborative & $\begin{array}{l}\text { Changes in resolutions style found after } \\
\text { psychoeducational intervention }\end{array}$ \\
\hline 29 & Compromising & Collaborative & $\begin{array}{l}\text { Changes in resolutions style found after } \\
\text { psychoeducational intervention }\end{array}$ \\
\hline 30 & Competitive & Compromising & $\begin{array}{l}\text { Changes in resolutions style found after } \\
\text { psychoeducational intervention }\end{array}$ \\
\hline
\end{tabular}




\section{Discussion}

The results of the psychoeducational intervention show that there was an increase in knowledge and understanding of conflict resolution styles. Then, another result shows that most of the participants chose a different conflict resolution style, i.e the collaborative and compromising style, when dealing with conflicts with their partners. Some participants chose to change the resolution style because the style used previously had not been effective, so they chose another style to be applied when facing conflict. Meanwhile, those who did not change the resolution style, considered that the styles (compromising, collaborative, avoidance) those had been used were effective in overcoming conflicts during their commuter marriage.

Thomas (1974) stated that the collaborative style is the most appropriate style for conflicting couples because it allows each partner to work together in finding the most effective solution for each other and meet each other's needs. Thomas and Kilmann (1975) further explained that by applying a collaborative style, couples can openly discuss their own complaints and problems and try to find the most effective solution for each partner and to improve the quality of their relationship. However, to see if the conflict resolution you choose is constructive or destructive, depends on how functional or dysfunctional the implementation is. A constructive conflict resolution style will involve open conversation, accepting the partner's point of view, and a commitment to problem-solving. While the destructive conflict resolution style refers to hostile and competitive behavior and avoidance (Rubenstein \& Feldman, 1993 in Delatorre \& Wagner, 2019).

Based on the explanation, participants who chose a resolution style, i.e. collaborative, compromising, and accommodative, had chosen and used a constructive resolution style. Meanwhile, participants who chose and continued to use competitive and avoidance styles indicated that they used destructive conflict resolution styles. Successful conflict resolution has a relationship between attachment and marital quality, which uses a constructive conflict resolution style. On the other hand, a destructive resolution style can lead to violent acts in marriage and affect the quality of the marriage (Bonache, Gonzalez-Mendez, \& Krahé, 2019). However, in this intervention, psychoeducators did not observe how far the resolution relationship could affect the quality of their marriage. This intervention only provides education regarding the choice of conflict resolution styles that can be applied by participants, both constructive and destructive styles. 
Psychoeducation provides information and education and knowledge to someone. This psychoeducation method, can increase knowledge, understanding of conflict resolution styles, and examples of behavior when dealing with conflict. Ahmad, Pulungan, and Hardiyati (2019) found psychoeducation is a preventive measure by providing information, problem-solving and communication skills exercise, and identification of marital stressors. Lestari (in Rosmaharani, Wihastuti and Supriati, 2015) added that psychoeducation can influence the level of knowledge among families and decrease partners' anxiety caused by the conflict. Based on these findings, it can be concluded that during the intervention most of the participants had tried to evaluate their condition when facing conflict with the new information provided by the psychoeducator. Psychoeducational interventions were also effective in providing participants with new information and understanding about the conflict resolution styles they could choose to use in their commuter marriage.

\section{Conclusion}

Based on the results of the study, it can be concluded that through this psychoeducational intervention, there was an increase in participants' knowledge and understanding. Then, some participants chose to change the conflict resolution style that was constructive and considered effective to be applied.

\section{Acknowledgement}

Researchers and Psychoeducators express their gratitude for the contributions of fellow lecturers and students of UNIKA Atma Jaya who were involved in this intervention. Especially to participants who are willing to take the time to provide data and participate in this psychoeducational intervention. These studies and interventions are conducted under a grant for graduate students.

\section{References}

Ahmad, M., Pulungan, Z.S.A \& Hardiyati. (2019). Psikoedukasi meningkatkan peran keluarga dalam merawat klien gangguan jiwa. [Psychoeducation increases family role in treating clients with psychological disorders] Jurnal Keperawatan Vol. 11 (3), 191 -198.

A'yun, Q. (2020). Gambaran Digital Family Communication Pattern dan Kepuasan Pernikahan pada Pasangan commuter marriage. [ Digital family communication patterns 
and marital satisfaction about commuter marital couples]. Tesis. Jakarta: UNIKA Atma Jaya.

Bonache, H., Gonzalez-Mendes, R \& Krahé, B. (2019). Adult attachment styles, destructive conflict resolution, and the experience of intimate patner violence. Journal of Interpersonal Violence, 34, 287-309.

Delatorre, M.Z \& Wagner, A. (2019). How do couples disagree? An analysis of conflict resolution profiles and the quality of romantic relationships. Evista Colombiana De Psicología, Vol. 28 No. 2, Page 91-108

Griffiths, P. (2006). An Introduction to English Semantics and Pragmatics. Edinburgh: Edinburgh University Press Ltd.

Gross, H. E \& Gerstel, N. (1982). Commuter Marriage: Marriage and Family Review. Journal of Human Relations. Vol. 5 (2), 71-9.

Handayani, Y. (2016). Komitmen, conflict resolution, dan kepuasan perkawinan pada istri yang menjalani hubungan pernikahan jarak jauh (Karyawan Schlumberger Balikpapan). PSIKOBORNEO Vol. 4 (3): 518 - 529.

Maharani, F \& Kinanthi, M.R. (2018). Peran komitmen pernikahan tipe personal dedication terhadap kepuasan pernikahan pada individu yang menjalani commuter marriage. [The role of personal dedication type martial commitment towards martial satisfaction amoing individuals in commuter marriages] Jurnal Pemikiran dan Penelitian Psikologi Vol. 14 (1):15-36.

Marriage \& family encyclopedia. (2009). Commuter marriage. Downloaded at http://famii.jrank.org/pages/296/commuter-marriage.html.

Muliadi, G.M. (2017). Relationship maintenance dalam commited romantic relationship pasangan suami istri yang menjalani commuter marriage. Journal E-Komunikasi Vol. 5 (1).

Nadia., Janah, N., \& Bustaman, N. (2017). Hubungan Resolusi Konflik Pasangan Suami Istri Bekerja dengan kepuasan Pernikahan pada Usia Pernikahan 3-5 Tahun.[The relationship between couples conflict resolution and marital satisfaction in 3-5 years of marital relationship]. Jurnal Bimbingan Konseling, Universitas Syiah Kuala (SULOH) Vol 2 (2).

Nastiti, B.S \& Wismanto, B. (2017). A study on the marriage phenomenolgy of commuter marriage spouse. Jurnal Ilmu Pendidikan, Psikologi, Bimbingan dan Konseling, Vol. 7 (1): $16-22$.

Rahma, M., \& Anwar, Z. (2015). Psikoedukasi Tentang Risiko Perkawinan Usia Muda untuk Menurunkan Intensi Pernikahan Dini pada Remaja. [Psychoeducation on the risks young 
of marital age to decrease marital intentions among adolescents] Jurnal Intervensi Psikologi, Vol. 7 (2).

Rosmaharani, S., Wihastuti, T.A \& Supriati, L. (2015). Pengaruh psikoedukasi keluarga terhadap perubahan tingkat kecemasan dan persepsi beban keluarga merawat anak dengan retardasi mental di SDLB negeri kabupaten Jombang. [The influence of family psychoeducation on changes of anxiety level and perception of burden among families with mentally-reatrded children attending special needs schools in the district of Jombang]. The Indonesian Journal of Health Science, Vol. 5 (2).

Rossalia, N., \& Priadi, M.A.G. (2018). Conflict Management Style pada Pasangan Suami Istri yang Tinggal Bersama Mertua. [Conflict management style among martial couples living with their parents-in-laws] Jurnal Ilmiah Psikologi MANASA, Vol. 7 (1), 35-50.

Sadarjoen, S.S. (2005). Konflik Marital: Pemahaman Konseptual, Aktual dan Alternatif Solusinya. [Marital conflicts: understanding of conceptual, actual and alternative solutions]. Bandung: Refika Aditama.

Thomas, K.W. \& Kilmann, R.P. (1974). Thomas Kilmann conflict mode instrument. CA: Mountain View. Xicom and CPP. 